Article

\title{
Can the Application the Silicon Improve the Productivity and Nutritional Value of Grass-Clover Sward in Conditions of Rainfall Shortage in Organic Management?
}

\author{
Grażyna Mastalerczuk ${ }^{1, *(1)}$, Barbara Borawska-Jarmułowicz ${ }^{1}$, Piotr Dąbrowski ${ }^{2}$, Ewa Szara ${ }^{3}$, \\ Aneta Perzanowska ${ }^{1}$ and Barbara Wróbel ${ }^{4}$ (D) \\ 1 Department of Agronomy, Institute of Agriculture, Warsaw University of Life Sciences-SGGW, Faculty of \\ Agriculture and Biology, Nowoursynowska 159 Str., 02-776 Warsaw, Poland; \\ barbara_borawska_jarmulowicz@sggw.edu.pl (B.B.-J.); aneta_perzanowska@sggw.edu.pl (A.P.) \\ 2 Department of Environmental Development, Faculty of Civil and Environmental Engineering, \\ Warsaw University of Life Sciences-SGGW, Nowoursynowska 159, 02-776 Warsaw, Poland; \\ piotr_dabrowski@sggw.edu.pl \\ 3 Department of Agricultural Chemistry, Institute of Agriculture, Warsaw University of Life Sciences-SGGW, \\ Faculty of Agriculture and Biology, Nowoursynowska 159 Str., 02-776 Warsaw, Poland; \\ ewa_szara@sggw.edu.pl \\ 4 Institute of Technology and Life Sciences (ITP), Falenty, Al. Hrabska 3, 05-090 Raszyn, Poland; \\ b.wrobel@itp.edu.pl \\ * Correspondence: grazyna_mastalerczuk@sggw.edu.pl; Tel.: +48-22-5932710
}

Received: 19 June 2020; Accepted: 10 July 2020; Published: 13 July 2020

\begin{abstract}
To improve sward efficiency and maintain high feed quality in organic farming-as well as compensate for yield losses under anticipated drought periods-alternative fertilization practices should be considered. In this context, this study aimed to assess the response to summer drought of grass-clover sward in organic cultivation under various conditions of foliar fertilization with silicon $(\mathrm{Si}$ ) (without $\mathrm{Si}$, $\mathrm{Si}$ applied with multicomponent fertilizer Herbagreen, $\mathrm{Si}$ applied with growth stimulator Optysil). The research was conducted at the certified organic field in the 3rd, 4th and 5th year of mowing utilization (from 2015 to 2017). The studies demonstrated a beneficial effect of Si application on the yield of the grass-clover sward, especially under multicomponent fertilizer. Both fertilizers increased roots mass, but growth stimulator (containing mainly $\mathrm{Si}$ ) had a stronger impact, especially with rainfall scarcity. In such conditions the application of Si decreased flavones concentration in plants and increased values of chlorophyll index. This study also indicated the potential for applying Si fertilizers to improve content of nutrients (crude protein, organic matter digestibility, potassium and phosphorus) in the sward. The results of presented studies may be used in fertilization practice of organic crop for enhancing sward productivity and to compensate for yield losses under condition of rainfall deficiency.
\end{abstract}

Keywords: grass-clover mixture; Lolium perenne L.; nutrients; organic farming; silicon; summer drought; Trifolium pratense L.

\section{Introduction}

Summer droughts observed in recent years because of global climate change are a serious agronomic problem. They are also the most important factor contributing to crop yield losses on grasslands. In temperate regions, periods with rainfall shortage are expected to increase in frequency and severity. Drought events can affect yield of grasslands very differently depending on the site conditions such 
as soil type, pre-drought climatic conditions and the intensity of management [1,2]. Combining soil and weather data with characteristics of grassland management in a simple model allowed a better prediction of herbage production [3]. According to Vogel et al. [4], low mowing frequency increases drought resistance of plants. In the advanced development phase, the plants are characterized by a better developed root system and are less sensitive to lack of rainfall. Moreover, the number of species and aboveground biomass are positively related even under drought conditions, which shows that biomass yield is higher the more diverse a plant community is. However, low management intensity is more important for high resistance against drought than species richness.

Currently, grasslands production are dominated by monocultures of Lolium perenne because of its suitability for grazing, high palatability for cattle and high yield potential. This species is also known for its rapid drought response because it requires a relatively large amount of water to maintain growth. Based on its agronomic characteristics, Trifolium repens is normally grown as a highly productive mixture with L. perenne [5]. Due to their ability to fix atmospheric nitrogen, legumes (Trifolium pratense and Trifolium repens) are considered as complementary species to highly productive swards and less dependent on external nitrogen $(\mathrm{N})$ inputs. This could be a valuable trait where plant-available soil $\mathrm{N}$ is increasingly constrained under drought [6].

Organic farming, characterized by low use intensity, is an alternative to intensive agriculture and to its negative impact on the environment, biodiversity and product quality. It stand out by a higher share of grassland, which are the basic feed base in animal production, compared to conventional farms. In such farming grazing plays an important role in many regions of the world. Furthermore, it presents a range of problems including variable and unpredictable herbage growth connected with weather conditions, lower daily herbage intake and output per animal, as well as lower efficiency of $\mathrm{N}$ use and often inefficient grazing management [7]. These cause increase to trends towards more frequent cutting sward and limit grazing in dairy farming. Moreover, low yield of dry matter (not exceeding four tons per hectare) and poorer quality of obtained fodder from natural grassland induces farmers to obtain additional forage area for animals from temporary grassland. Grass-clover mixtures cultivated on arable land, used for mowing, grazing or silage production, supplement the missing amount of fodder resulting from the lower level of permanent grassland yielding [8]. Temporary grasslands in organic cultivation with a high share of legume plants allows for obtaining fodder and animal products of better quality with significantly positive environmental impact affecting mainly water cycling [9]. Feeds from temporary grasslands, compared to those obtained from permanent, are better balanced in terms of protein, energy, as well as macro- and microelements $[5,10]$.

On organic farms, the issue of proper plant nutrition plays a key role. The abandonment of chemical fertilizers in favor of biologic and mineral products encourages scientists and farmers to look for new opportunities to improve plant productivity. The solution to the problem may be research on the impact of the use of silicon-containing fertilizers on the yield and feed value of grassland sward. The use of silicon (Si) to fertilize plants is showing increasing interest in many countries [11]. Many studies have shown, that use of Si fertilizers affects the yielding and the quality of useful parts of plants [12-15]. An improvement in the intensity of physiological and metabolic processes due to Si fertilization was found as well [16,17]. The beneficial effects of $\mathrm{Si}$ are also associated with higher plants resistance to biotic and abiotic stress [18]. Silicon supply improves osmoregulation, plant water status, reduces in water loss by transpiration, ensures maintenance of adequate supply of essential nutrients, limits toxic ions uptake and provides efficient functioning of antioxidative mechanisms [16,19-21]. Plants growing under conditions of water stress, as a result of Si fertilization, show increased activity of antioxidant enzymes (e.g., superoxide dismutase-SOD, peroxidase-POD, catalase-CAT and ascorbate peroxidase-APX) and a higher concentration of antioxidants. Plants characterized by higher of proline (Pro) and glycine betaine (GB) and soluble protein content as well [22]. Furthermore, the application of Si encouraging the development of a root system [23]. According to the literature, $\mathrm{Si}$ has a role in enhancing root elongation and in protecting the stele as a mechanical barrier by hardening the cell wall of the stele and endodermal tissues. This beneficial effects of Si are restricted to 
young and immature tissues such as the apical part of the root and the basal part of the leaf in plants in Poaceae [24]. The reaction of plant species to Si fertilization and also the mechanisms of Si absorption are different between plant species [25]. Much research concerns agricultural and horticultural plants cultivated on arable land, although their results are often ambiguous $[11,14,17]$. There is still insufficient information in the literature about the impact of silicon fertilization on grassland plants, especially in the context of repeated periods of drought. Therefore, there is a need to continue experiments that may allow to understand better the interactions between silicon application and plant response, especially in grass-clover mixture sward in the environmentally friendly organic cultivation.

This study therefore aimed to assess the morphologic, physiological and quality response of grass and clover species to summer drought of in organic cultivation under different condition of silicon fertilization. We focused on the following questions: (1) How does grass-clover sward as well as belowground biomass of plants in organic cultivation respond to silicon fertilization under summer drought? (2) Are the values of the physiological parameters of Lolium perenne and Trifolium pratense under the influence of silicon-containing fertilizers similar in case of rainfall deficiency? (3) How does silicon fertilization affect the content of nutrients in sward of temporary grassland in organic farming?

\section{Materials and Methods}

\subsection{Experimental Site}

The research was conducted at the certified organic field in Experimental Station of the Institute of Agriculture of Warsaw University of Life Sciences-SGGW (Poland, Skierniewice, 51 $57^{\prime} \mathrm{N}, 20^{\circ} 9^{\prime} \mathrm{E}$ ). In autumn 2012, on arable land grass-clover mixture was sown with the following composition: perennial ryegrass (Lolium perenne L., cv. Solen), red clover (Trifolium pratense L., cv. Nike) and white clover (Trifolium repens L., cv. Grasslands Huia) in a 1:1:1 ratio. The experiment was established on Luvisol soils of the texture of loamy sand [26]. The soil was slightly acidic and characterized by medium potassium, very low phosphorus and very high magnesium content (Table 1). Sward was mowed three times during the growing season every year. The studies were carried out in the $3 \mathrm{rd}$, 4 th and 5 th year of utilization (in the year 2015, 2016 and 2017, respectively). After this period, soil properties changed and showed low potassium content and medium phosphorus levels.

Table 1. Soil properties in the field experiment before (2015) and after study period (2017) and dates of plant mowing during the study period.

\begin{tabular}{|c|c|c|c|c|}
\hline Year & $\mathrm{pH}_{\mathrm{KCl}}$ & $\mathbf{P}$ & $\begin{array}{c}\mathbf{K} \\
\mathrm{mg} / 100 \mathrm{~g} \text { soil }\end{array}$ & $\mathbf{M g}$ \\
\hline 2012 & 5.6 & 3.2 & 14.9 & 10.7 \\
\hline 2017 & 5.8 & 13.1 & 6.1 & 12.1 \\
\hline \multicolumn{5}{|c|}{ Mowing dates } \\
\hline & $1 \mathrm{st}$ & 2nd & $3 r d$ & \\
\hline 2015 & 27 May & 20 July & $7 \mathrm{Oct}$ & \\
\hline 2016 & 25 May & 17 July & 28 Sep & \\
\hline 2017 & 2 June & 17 July & 26 Sep & \\
\hline
\end{tabular}

Two kinds of foliar silicon (Si) fertilizers, allowed for use on organic farms, were used. The first one multicomponent named Herbagreen (NaturalCrop Poland Sp., Warsaw, Poland) contained silicon, calcium and other nutrients $\left(\mathrm{CaO}-36.7 \%, \mathrm{SiO}_{2}-17 \%, \mathrm{Fe}_{2} \mathrm{O}_{3}-3.4 \%, \mathrm{MgO}-2.4 \%, \mathrm{~K}_{2} \mathrm{O}-0.7 \%\right.$, $\mathrm{Na}_{2} \mathrm{O}-0.5 \%, \mathrm{TiO}_{2}-0.5 \%, \mathrm{SO}_{3}-0.4 \%, \mathrm{P}_{2} \mathrm{O}_{5}-0.2 \%, \mathrm{MnO}-0.1 \%$ and trace amounts $\mathrm{B}, \mathrm{Co}, \mathrm{Cu}, \mathrm{Zn}$ ). The second growth stimulator named Optysil (Intermag Sp.,, Olkusz, Poland) contained silicon $\left(\mathrm{SiO}_{2}\right)$ mainly ( $200 \mathrm{~g} \mathrm{SiO}_{2}-16.5 \%$; and $24 \mathrm{~g} \mathrm{Fe} / \mathrm{L}$ ). Three fertilization variants were used: no fertilizer (control), Herbagreen $(4 \mathrm{~kg} / \mathrm{ha})$ and Optysil $(1 \mathrm{~L} / \mathrm{ha})$ per each regrowth. Fertilizers were applied twice $(4$ and 2 weeks before each harvesting). Each treatment was replicated three times and the experiment was 
carried out as a complete randomized block design. The area of the entire experimental facility was $945 \mathrm{~m}^{2}$ and the separated plot of $105 \mathrm{~m}^{2}(7 \mathrm{~m} \times 15 \mathrm{~m})$.

\subsection{Evaluation of Plant Productivity}

The botanical composition of sward was determined in each regrowth by botanical-weight analysis. Sown and other species (weeds) were separated in the samples (500 g) obtained from each plot. Yields of dry matter (YDM; $\mathrm{t} / \mathrm{ha}$ ) was determined at each harvest. In autumn (October), after the third harvest in each year of research, roots dry biomass of plants (RDM; $\mathrm{kg} / \mathrm{m}^{2}$ ) and stubble mass $\left(\mathrm{SDM} ; \mathrm{kg} / \mathrm{m}^{2}\right)$ were evaluated by a soil core-break technique [27]. For this purpose, soil-plant samples (three per plot) were taken by using a hydraulic breaker (Atlas Copco, Stockholm, Sweden). Plants were cut above tillering nodes, what allowed to separate a $5 \mathrm{~cm}$ layer of stubble. Soil-roots samples were divided into three layers of $10 \mathrm{~cm}(0-10,10-20,20-30)$. Roots were separated from the soil by washing on sieves in a stream of running water. Then the roots were dried at $70{ }^{\circ} \mathrm{C}$ until a constant weight was reached and cleaned from organic parts by hand. The roots were weighed, and the results expressed in $\mathrm{kg} / \mathrm{m}^{2}$. From these primary data the harvest index (HI) values were estimated as the ratio of useful yield to biologic yield of plants (Equation (1)):

$$
\mathrm{HI}=\mathrm{YDM} /(\mathrm{YDM}+\mathrm{SDM}+\mathrm{RDM})
$$

In order to determine the productivity of aboveground biomass of plants leaf area index (LAI) measurements were made. The study was conducted using a portable AcuuPAR LP-80 meter (Decagon Devices, Inc., Pullman, WA, USA) equipped with a linear sensor of photosynthetically active PAR radiation, measuring radiation intensity from 0 to over $2500 \mu \mathrm{mol} / \mathrm{m}^{2} / \mathrm{s}$ over a $84 \mathrm{~cm}$ length. LAI parameter measurements were made between 10-12.00 a.m., on the day of the harvesting (five per plot).

\subsection{Determination of the Relative Content of Flavonols and Chlorophyll}

The relative chlorophyll (Chl) and epidermal flavonols (FLV) content were determined in each year using by hand-held leaf-clip sensor Dualex Scientific+ (FORCE-A, France). The measurements were carried out on the day of harvesting, on the central part of mature, fully developed leaf blade of L. perenne and T. pratense, in accordance with a standard protocol recommended by the apparatus manufacturer. Five measurements were taken per each plot. The parameter values expressed in relative units.

\subsection{Nutritive Value Analyses}

The nutritive value of sward were determined twice - in second and third year of study (2016 and 2017, respectively). The content of potassium, magnesium, calcium and sodium in plants was determined by atomic absorption spectrometry (AAS) while phosphorus by colorimetric method.

The nutrient content of the grass-clover sward: crude protein $(\mathrm{CP})$, crude fiber $(\mathrm{CF})$ and organic matter digestibility (OMD) in dry matter was analyzed using the NIRS method on near-infrared spectrometer NIRFlex N-500 (Büchi Labortechnik AG, Flawil, Switzerland) with ready-made meadow hay calibrations.

\subsection{Statistical Analysis}

The statistical analysis of the data was performed using the Statistica 13.3 software (Statsoft, Inc., Tulsa, OK, USA). Experiment was carried out as a complete randomized block design. Three fertilization variants were used: no fertilizer (control), Herbagreen and Optysil. Each treatment was replicated three times. The experimental data were analyzed using multifactorial analysis of variance (ANOVA). The significance of differences between means was determined using the Tukey HSD test at the significance level of 0.05 . In order to assess the relationships between the physiological parameters and 
the features of the structure of plant biomass and also nutrients content Pearson correlation coefficients between pairs of traits were evaluated and principal component analysis (PCA) were performed.

\section{Results}

\subsection{Weather Conditions}

It was noted that the weather conditions were very diverse in the study period, especially with regard to the amount and distribution of rainfall. During the vegetation periods it was, respectively: in the first year (2015) —270 mm, the second year (2016) —470.1 mm, the third year (2017) —607.7 mm. According to Vinczeffy [28], optimal conditions for meadow plants growth occurs when rainfall is $0.2 \mathrm{~mm}$ per $1^{\circ} \mathrm{C}$. Vinczeffy's climatic index allowed qualifying subsequent years of research (2015, 2016 , 2017) in terms of hydrothermal conditions as very dry, moderately moist and rainy, respectively (Figure 1).

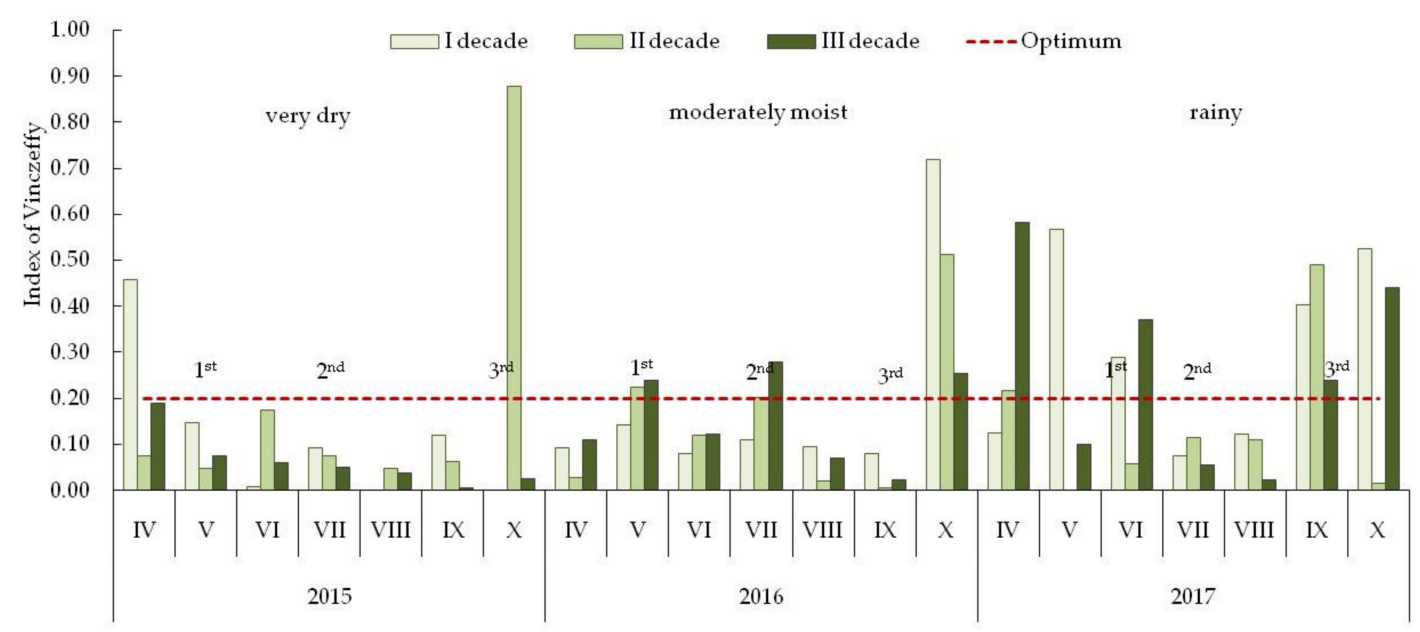

Figure 1. Vinczeffy hydrothermal index for subsequent 10 days of month (decade: I, II, III) during the vegetation period in 2015-2017 (1st, 2nd, 3rd-mowing).

In 2015, the hydrothermal conditions reached the optimum level for plant growth only in the spring (in April, climatic index 0.24). Rainfall deficiency was unfavorable for plants growth just during the second regrowth. The index of Vinczeffy has not exceeded 0.125 since the third decade (last 10 days) of June. High temperature and lack of rainfall in the first half of August and also low rainfall in September strongly limited the third regrowth of plants. In late autumn and winter, the air temperature was not too low, which favorably affected the wintering of plants. In April 2016, a slight amount of rainfall was noted, however, moderate temperatures and sufficient moisture in May (climatic index 0.20) favored the development of plants during the first regrowth. Quite dry June and the first half of July (climatic index 0.12) strongly reduced plant growth before the second harvest. While slight rainfall in August and September also limited the last regrowth (index value 0.06 and 0.04, respectively, which classifies this period as disastrously dry). The amount and distribution of rainfall in the growing season 2017 was more favorable for plant growth compared to the previous years. However, the periodic lack of rainfall in the second half of May slightly reduced spring regrowth of plants. A small amount of rainfall was also recorded in July and August (climatic index approximately $0.08)$, which could have limited plant growth before the third harvest.

\subsection{Botanical Composition and Plant Productivity}

The research showed not clear effect of the foliar application of silicon-containing fertilizers on the botanic composition of grass-clover sward. However, a change in the share of sown species in individual regrowth was found (Figure 2). L. perenne dominated in the first regrowth (over $80 \%$ in the 
first and second year of study and approximately 50\% in last year). Legume plants (T. pratense and T. repens) were dominated in subsequent two regrowths. In the first and second year, T. pratense was characterized by a higher share, while in the third year-T. repens. Non-sown species (other sp.) were present in the sward in low share (annual mean up to 10\%). Their higher share (approximately 20\%) was found in the last regrowth in the first year of study (2015) and in the first regrowth in the third year (2017) as well.

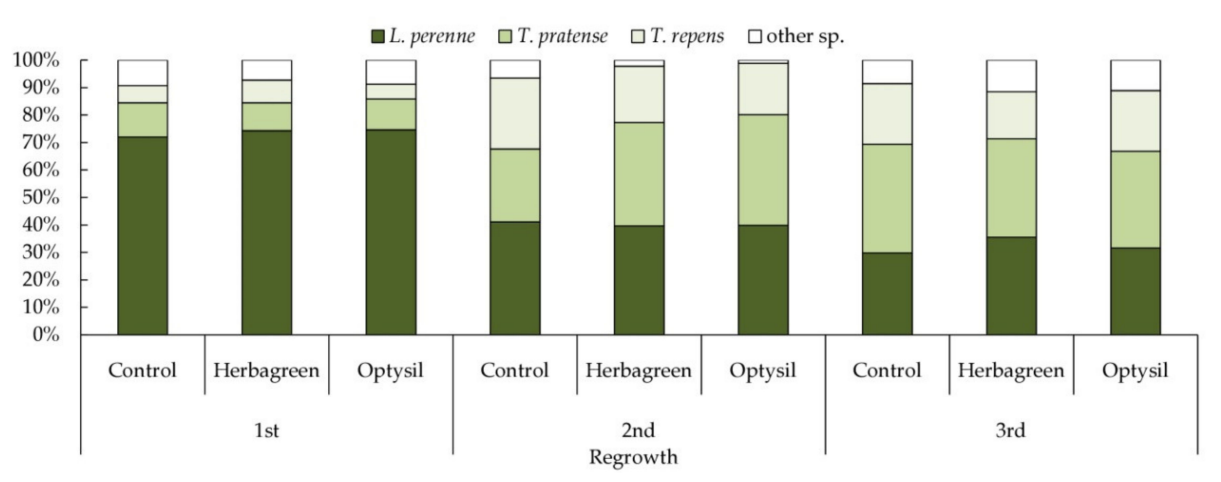

Figure 2. Botanical composition of grass-clover sward (\%) in regrowths (1st, 2nd, 3rd) in the study period (mean 2015-2017).

Our studies demonstrated the effect of fertilizers containing Si on the yield of the grass-clover sward. The yield on control treatment (regardless of other factors) was significantly lower compared to this obtained on fertilized objects, especially under multicomponent Herbagreen (Table 2). Differences in annual yield in subsequent years of study were also shown. It was influenced by weather conditions during the growing season. Plants yielded the best in the rainy, third year of research (2017). Simultaneously, in each year the application of Si fertilizers had a positive effect on the annual yield of sward (not significant in relation to Optysil fertilization in the second year of study).

Table 2. The yield of dry matter of the grass-clover sward (YDM; $t / h a)$ and their percentage share in annual yield (2015-2017) depending on the application of fertilizers containing silicon (Herbagreen, Optysil).

\begin{tabular}{|c|c|c|c|c|c|c|c|c|c|c|c|c|c|}
\hline \multirow{3}{*}{ Treatment } & \multicolumn{13}{|c|}{ Year/Regrowth } \\
\hline & \multicolumn{3}{|c|}{2015} & \multicolumn{3}{|c|}{2016} & \multicolumn{3}{|c|}{2017} & \multicolumn{3}{|c|}{ Annual (Year $\times$ Treatment) } & \multirow{2}{*}{$\frac{2015-2017}{\text { Mean }}$} \\
\hline & 1st & 2nd & $3 \mathrm{rd}$ & 1st & 2nd & 3rd & 1st & 2nd & 3rd & 2015 & 2016 & 2017 & \\
\hline Control & $4.71 \mathrm{a}$ & $1.69 \mathrm{a}$ & $0.33 a$ & $3.63 a$ & $0.63 a$ & $2.46 a$ & $3.06 \mathrm{a}$ & $3.34 \mathrm{a}$ & $1.83 a$ & $6.74 a$ & $6.72 a$ & $8.23 b$ & $7.23 \mathrm{a}$ \\
\hline Herbagreen & $5.11 \mathrm{a}$ & $2.46 a$ & $0.41 \mathrm{a}$ & $4.04 \mathrm{a}$ & $0.99 b$ & $3.18 b$ & $4.29 \mathrm{~b}$ & $3.38 \mathrm{a}$ & $1.90 \mathrm{a}$ & $7.98 b$ & $8.22 b$ & $9.58 \mathrm{c}$ & $8.59 c$ \\
\hline Optysil & $5.20 \mathrm{a}$ & $2.36 a$ & $0.56 a$ & $3.84 a$ & $0.68 \mathrm{a}$ & $2.53 \mathrm{a}$ & $3.91 b$ & $3.62 a$ & $1.93 a$ & $8.13 b$ & $7.05 a$ & $9.46 c$ & $8.21 b$ \\
\hline Mean & & & & & & & & & & $7.79 \mathrm{~A}$ & $7.45 \mathrm{~A}$ & $9.26 \mathrm{~B}$ & \\
\hline$\%$ share & 65.0 & 29.0 & 6.0 & 52.0 & 11.0 & 37.0 & 42.0 & 37.0 & 21.0 & & & & \\
\hline
\end{tabular}

Data in columns marked with the same lowercase $(a, b, \ldots)$ or in rows-uppercase $(A, B)$ letters do not differ significantly according to Tukey's test $(p \leq 0.05)$.

In subsequent years, the distribution of yields in regrowths was strongly modified by weather conditions. In the first year (2015), drought in August and September particularly strongly reduced the third regrowth of plants (share in annual yield of 6\%). In the following year (2016), rainfall deficiency and high air temperature in June-July period significantly reduced the yield of the second regrowth (11\% share in annual yields). While, in the last year of research (2017) was distinguished by the most favorable conditions for plant development. Despite the low rainfall in July and August, high humidity and moderate temperatures in September allowed plants to regenerate the above-ground part and the third plant regrowth gave a satisfactory yield. Yield distribution in regrowths was favorable (Table 2).

Weather conditions during the study period affected the root mass of plants in layer of soil 0-30 cm (Table 3). Plants were characterized by a significantly more mass of roots in 2015 and 2016 with a lack of rainfall. In rainy 2017 , it was less-by $21.3 \%$ and $16.4 \%$, respectively. The studies revealed the 
impact of the application of fertilizers containing Si on the mass of plant roots as well. Both fertilizers increased roots mass, however more strongly on the below-ground part of plant influenced Optysil, containing Si mainly. Simultaneously, regardless of the year of research, Herbagreen increased the mass of roots in a layer of 0-10 cm, while Optysil affected deeper, up to $20 \mathrm{~cm}$.

Table 3. Dry root mass of plants $\left(\mathrm{RDM} ; \mathrm{kg} / \mathrm{m}^{2}\right)$ in the soil layer up to $30 \mathrm{~cm}$ depending on silicon-containing fertilizer treatments (Herbagreen, Optysil) in the years of study.

\begin{tabular}{|c|c|c|c|c|c|c|c|c|c|}
\hline Year & \multicolumn{3}{|c|}{2015} & \multicolumn{3}{|c|}{2016} & \multicolumn{3}{|c|}{2017} \\
\hline $\begin{array}{l}\text { Treatment/Layer } \\
\text { (cm) }\end{array}$ & 0-10 & $10-20$ & $20-30$ & 0-10 & $10-20$ & $20-30$ & 0-10 & $10-20$ & $20-30$ \\
\hline Control & $1.33 \mathrm{a}$ & $0.19 a$ & $0.08 \mathrm{a}$ & $1.20 \mathrm{a}$ & $0.17 \mathrm{a}$ & $0.15 a$ & $1.20 \mathrm{a}$ & $0.17 \mathrm{a}$ & $0.06 a$ \\
\hline Herbagreen & $1.74 b$ & $0.24 a$ & $0.13 a$ & $1.51 b$ & $0.19 a$ & $0.13 a$ & $1.42 b$ & $0.14 a$ & $0.09 a$ \\
\hline Optysil & $1.69 \mathrm{~b}$ & $0.40 \mathrm{~b}$ & $0.18 \mathrm{a}$ & $1.93 c$ & $0.20 \mathrm{a}$ & $0.14 a$ & $1.30 \mathrm{ab}$ & $0.34 b$ & $0.07 \mathrm{a}$ \\
\hline Year & \multicolumn{3}{|c|}{ Mean 2015-2017 } & 2015 & 2016 & 2017 & \multicolumn{3}{|c|}{ Mean 2015-2017 } \\
\hline $\begin{array}{l}\text { Treatment/Layer } \\
\text { (cm) }\end{array}$ & 0-10 & $10-20$ & $20-30$ & & $0-30$ & & \multicolumn{3}{|c|}{$0-30$} \\
\hline Control & $1.24 \mathrm{a}$ & $0.18 \mathrm{a}$ & $0.10 \mathrm{a}$ & $1.60 \mathrm{a}$ & $1.53 \mathrm{a}$ & $1.42 \mathrm{a}$ & \multicolumn{3}{|c|}{$1.52 \mathrm{a}$} \\
\hline Herbagreen & $1.56 \mathrm{~b}$ & $0.19 a$ & $0.12 \mathrm{a}$ & $2.11 \mathrm{ab}$ & $1.83 a$ & $1.65 a$ & \multicolumn{3}{|c|}{$1.86 \mathrm{~b}$} \\
\hline Optysil & $1.64 b$ & $0.31 b$ & $0.13 a$ & $2.28 \mathrm{~b}$ & $2.27 \mathrm{~b}$ & $1.71 \mathrm{a}$ & \multirow{2}{*}{\multicolumn{3}{|c|}{$2.09 c$}} \\
\hline Mean & & & & $2.07 \mathrm{~B}$ & $1.95 \mathrm{~B}$ & $1.63 \mathrm{~A}$ & & & \\
\hline
\end{tabular}

Data in columns marked with the same lowercase $(a, b, \ldots)$ or in rows-uppercase $(A, B)$ letters do not differ significantly according to Tukey's test $(p \leq 0.05)$.

Studies have shown variability in plant productivity indices depending on the weather conditions in the years and also under Si application (Table 4). The highest HI value was recorded in 2017 (the most wet) and the lowest in 2016 (moderately moist). The application of Optysil, which increased root mass, caused a decrease in HI value, especially in 2016. Leaf area index fluctuated during study period and their value was the highest in 2017 (higher compared to other years by approximately 30\%). It was also found, that both silicon-containing fertilizers increased LAI value, significantly in 2015 and 2017.

Table 4. Impact of silicon-containing fertilizers (Herbagreen, Optysil) on plant productivity indices: harvest index (HI), leaf area index (LAI) and also chlorophyll index (Chl) and flavonol index (FLV) in L. perenne and T. pratense plants during the study period (2015-2017).

\begin{tabular}{|c|c|c|c|c|c|c|c|c|}
\hline \multirow{2}{*}{ Treatment } & 2015 & 2016 & 2017 & Mean & 2015 & 2016 & 2017 & Mean \\
\hline & \multicolumn{4}{|c|}{ HI } & \multicolumn{4}{|c|}{ LAI } \\
\hline Control & $0.25 \mathrm{a}$ & $0.22 b$ & $0.27 \mathrm{a}$ & $0.25 b$ & $1.37 \mathrm{a}$ & $1.79 a$ & $1.99 \mathrm{a}$ & $1.72 \mathrm{a}$ \\
\hline Herbagreen & $0.24 a$ & $0.22 b$ & $0.29 a$ & $0.25 b$ & $1.94 b$ & $1.93 \mathrm{a}$ & $2.80 \mathrm{~b}$ & $2.22 \mathrm{~b}$ \\
\hline Optysil & $0.23 \mathrm{a}$ & $0.18 \mathrm{a}$ & $0.27 \mathrm{a}$ & $0.23 a$ & $1.92 b$ & $1.82 \mathrm{a}$ & $2.68 \mathrm{~b}$ & $2.14 \mathrm{~b}$ \\
\hline \multirow[t]{3}{*}{ Mean } & $0.24 \mathrm{~B}$ & $0.20 \mathrm{~A}$ & $0.28 \mathrm{C}$ & & $1.82 \mathrm{~A}$ & $1.86 \mathrm{~A}$ & $2.59 \mathrm{~B}$ & \\
\hline & \multicolumn{4}{|c|}{ Lolium perenne } & \multicolumn{4}{|c|}{ Trifolium pratense } \\
\hline & \multicolumn{8}{|c|}{ Chl } \\
\hline Control & $28.9 a$ & $29.9 a$ & $23.1 \mathrm{a}$ & $27.3 a$ & $42.7 \mathrm{a}$ & $41.3 \mathrm{a}$ & $35.7 \mathrm{a}$ & $39.9 a$ \\
\hline Herbagreen & $34.8 \mathrm{~b}$ & $35.2 \mathrm{c}$ & $29.4 b$ & $33.1 b$ & $46.7 \mathrm{~b}$ & $42.3 a$ & $38.1 b$ & $42.4 b$ \\
\hline Optysil & $33.6 \mathrm{~b}$ & $33.5 b$ & $29.8 b$ & $32.3 b$ & $45.6 \mathrm{~b}$ & $42.7 \mathrm{a}$ & $39.5 b$ & $42.6 \mathrm{~b}$ \\
\hline \multirow[t]{2}{*}{ Mean } & $33.2 \mathrm{~B}$ & $33.5 \mathrm{~B}$ & $28.3 \mathrm{~A}$ & & $45.5 \mathrm{C}$ & $42.3 \mathrm{~B}$ & $38.1 \mathrm{~A}$ & \\
\hline & \multicolumn{8}{|c|}{ FLV } \\
\hline Control & $1.86 \mathrm{~b}$ & $1.78 \mathrm{~b}$ & $1.69 \mathrm{~b}$ & $1.77 \mathrm{~b}$ & $3.21 \mathrm{a}$ & $3.10 \mathrm{~b}$ & $2.80 \mathrm{a}$ & $3.03 \mathrm{~b}$ \\
\hline Herbagreen & $1.76 \mathrm{a}$ & $1.48 \mathrm{a}$ & $1.41 \mathrm{a}$ & $1.55 \mathrm{a}$ & $3.12 \mathrm{a}$ & $2.83 a$ & $2.70 \mathrm{a}$ & $2.89 a$ \\
\hline Optysil & $1.77 \mathrm{a}$ & $1.44 \mathrm{a}$ & $1.40 \mathrm{a}$ & $1.54 \mathrm{a}$ & $3.17 \mathrm{a}$ & $2.81 \mathrm{a}$ & $2.84 a$ & $2.94 \mathrm{ab}$ \\
\hline Mean & $1.78 \mathrm{C}$ & $1.52 \mathrm{~B}$ & $1.46 \mathrm{~A}$ & & $3.16 \mathrm{C}$ & $2.88 \mathrm{~B}$ & $2.78 \mathrm{~A}$ & \\
\hline
\end{tabular}

Data in columns marked with the same lowercase $(\mathrm{a}, \mathrm{b}, \ldots)$ or in rows-uppercase $(\mathrm{A}, \mathrm{B}, \ldots)$ letters do not differ significantly according to Tukey's test $(p \leq 0.05)$. 


\subsection{Relative Content of Flavones and Chlorophyll}

The relative chlorophyll content (shown by the Chl index) varied depending on the year of the study. In the years with limited rainfall, higher $\mathrm{Chl}$ values were found regarding to both L. perenne and T. pratense plants (Table 4). The research also showed the effect of Si fertilization on the Chl value. L. perenne plants significantly reacted by increasing the Chl content under the influence of $\mathrm{Si}$ application compare to the control every year. While, in T. pratense a significant increase in Chl values were demonstrated in the first and third year. In 2016, the tendency was similar, but the differences were not statistically significant.

Relative flavones content (demonstrated by the FLV index) in the epidermis of examined leaves changed in subsequent years of research. In both species tested, it was the highest in the very dry year (2015) and the smallest in the rainy year (2017) (Table 4). Foliar application of silicon-containing fertilizers on L. perenne plants reduced the FLV value in comparison to the objects without fertilization. The effect of both fertilizers were similar each year. In the case of $T$. pratense plants a significant reduction in the FLV value was evident only in the second year of the study (2016).

\subsection{Nutrient Content}

The content of nutrients in grass-clover sward varied during the years of research (Table 5). In 2017, which was distinguished by higher humidity, associated with the amount of precipitation $(607.7 \mathrm{~mm})$, compared to 2016, sward was characterized by a significantly higher content of crude protein, potassium, magnesium and higher digestibility of organic matter. At the same time, the phosphorus content of plants was lower.

Table 5. Nutritional value of the grass-clover sward depending on the application of fertilizers containing silicon.

\begin{tabular}{ccccccccc}
\hline \multirow{2}{*}{ Analyzed Component } & \multicolumn{3}{c}{$\mathbf{2 0 1 6}$} & & $\mathbf{2 0 1 7}$ & & $\mathbf{2 0 1 6}$ & $\mathbf{2 0 1 7}$ \\
\cline { 2 - 8 } & Control & Herbagreen & Optysil & Control & Herbagreen & Optysil & \\
\hline Crude protein $(\mathrm{g} / \mathrm{kg} \mathrm{DM})$ & $137.7 \mathrm{a}$ & $150.6 \mathrm{~b}$ & $140.3 \mathrm{a}$ & $172.8 \mathrm{a}$ & $185.8 \mathrm{~b}$ & $172.2 \mathrm{a}$ & $142.9 \mathrm{~A}$ & $176.9 \mathrm{~B}$ \\
Crude Fiber $(\mathrm{g} / \mathrm{kg} \mathrm{DM})$ & $243.8 \mathrm{~b}$ & $228.0 \mathrm{a}$ & $230.2 \mathrm{a}$ & $236.0 \mathrm{ab}$ & $231.0 \mathrm{a}$ & $237.2 \mathrm{~b}$ & $234.0 \mathrm{~A}$ & $234.7 \mathrm{~A}$ \\
Digestibility organic & $54.32 \mathrm{a}$ & $57.73 \mathrm{~b}$ & $56.74 \mathrm{~b}$ & $58.38 \mathrm{ab}$ & $59.41 \mathrm{~b}$ & $57.42 \mathrm{a}$ & $56.65 \mathrm{~A}$ & $58.41 \mathrm{~B}$ \\
matter $(\%)$ & $15.57 \mathrm{a}$ & $18.29 \mathrm{c}$ & $16.97 \mathrm{~b}$ & $16.89 \mathrm{a}$ & $19.45 \mathrm{~b}$ & $18.75 \mathrm{ab}$ & $17.22 \mathrm{~A}$ & $18.66 \mathrm{~B}$ \\
$\mathrm{~K}(\mathrm{~g} / \mathrm{kg} \mathrm{DM})$ & $2.90 \mathrm{a}$ & $3.20 \mathrm{~b}$ & $3.24 \mathrm{~b}$ & $1.17 \mathrm{a}$ & $1.41 \mathrm{~b}$ & $1.27 \mathrm{ab}$ & $3.16 \mathrm{~B}$ & $1.31 \mathrm{~A}$ \\
$\mathrm{P}(\mathrm{g} / \mathrm{kg} \mathrm{DM})$ & $2.20 \mathrm{a}$ & $2.17 \mathrm{a}$ & $2.18 \mathrm{a}$ & $2.74 \mathrm{a}$ & $2.61 \mathrm{a}$ & $2.57 \mathrm{a}$ & $2.18 \mathrm{~A}$ & $2.62 \mathrm{~B}$ \\
$\mathrm{Mg}(\mathrm{g} / \mathrm{kg} \mathrm{DM})$ & $8.46 \mathrm{a}$ & $9.48 \mathrm{~b}$ & $9.68 \mathrm{~b}$ & $11.18 \mathrm{a}$ & $9.17 \mathrm{a}$ & $10.38 \mathrm{a}$ & $9.36 \mathrm{~A}$ & $10.06 \mathrm{~A}$ \\
$\mathrm{Ca}(\mathrm{g} / \mathrm{kg} \mathrm{DM})$ & $0.57 \mathrm{a}$ & $0.67 \mathrm{~b}$ & $0.54 \mathrm{a}$ & $0.60 \mathrm{a}$ & $0.70 \mathrm{~b}$ & $0.53 \mathrm{a}$ & $0.60 \mathrm{~A}$ & $0.61 \mathrm{~A}$ \\
$\mathrm{Na}(\mathrm{g} / \mathrm{kg} \mathrm{DM})$ &
\end{tabular}

Data in the row marked with the same lowercase $(a, b, \ldots)$ letters in years between variants of fertilization and uppercase (A, B) letters between years do not differ significantly according to Tukey's test $(p \leq 0.05)$.

The research also showed the effect of the foliar application of silicon-containing fertilizers on sward nutrient content. Fertilization with multicomponent Herbagreen in both years of research resulted in an increase in the content of crude protein, potassium, phosphorus and sodium. In contrast, Optysil showed a stronger effect only in a moderately moist year (2016), while in 2017, there was no significant impact. Moreover, only in a year with less rainfall it was shown that both fertilizers reduced the content of crude fiber and increased the digestibility of organic matter.

PCA analysis showed that the first component accounted for $53.28 \%$ and the second $27.94 \%$ of the analyzed variability (Figure 3a). Silicon application in the study period the most affected CP, LAI, YDM and to a less extent DOM, HI, Mg and P. These parameters (except P) were significantly, positively correlated with each other. The highest values of these characteristics (YDM, LAI, DOM) were recorded in rainy year (2017) under Si application, especially using multicomponent Herbagreen (Figure 3b). Moreover, high-CF content of plants was associated with high relative FLV content (especially in L. perenne) and low DOM. High relative content of Chl in plants and high RDM was 
shown in moderately moist 2016 under Si application condition. Whereas the lack of Si in this year resulted in accumulation of CF and FLV by plants.
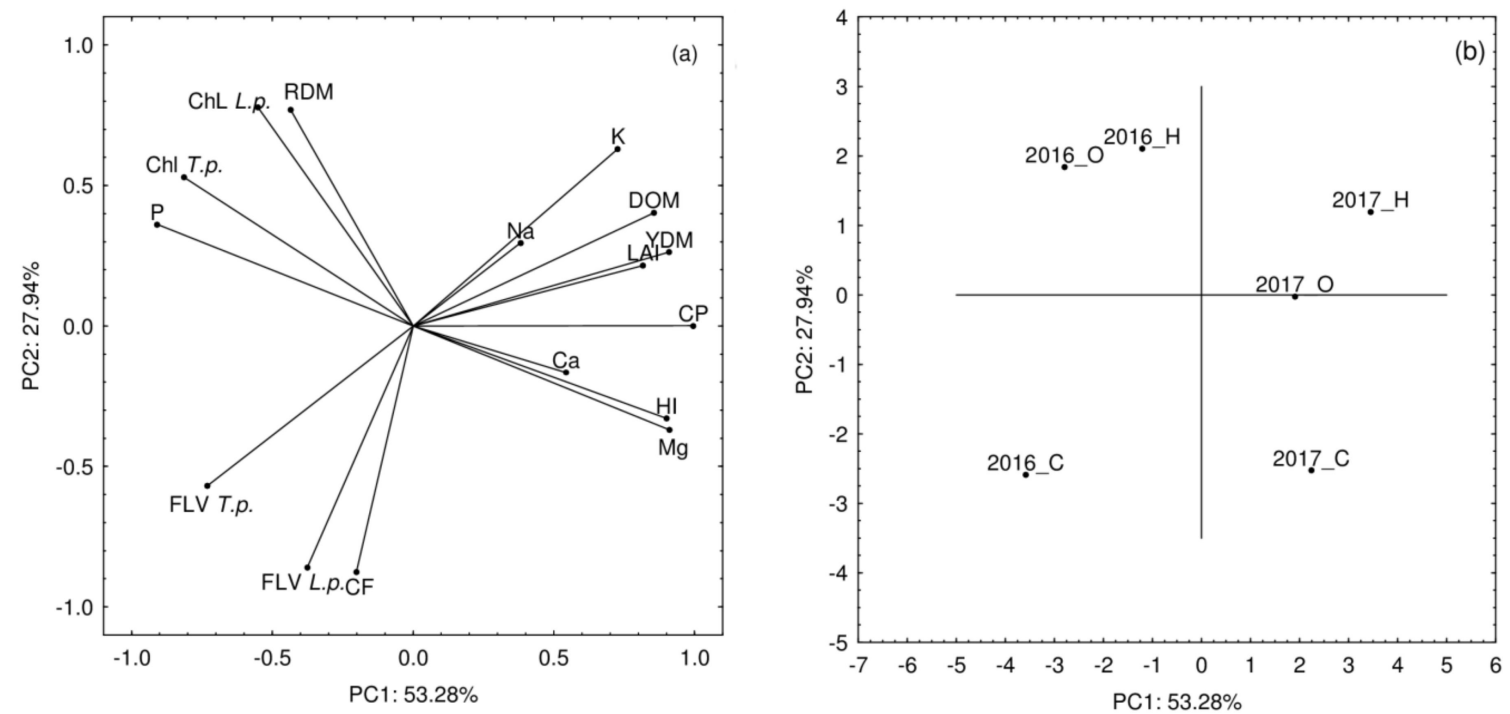

Figure 3. Results of principal component analysis (PCA) (a) presenting relationships between the traits: YDM-yield of dry matter, RDM-dry mass of roots, HI-harvest index, LAI-leaf area index, FLV L.p.- -relative flavones content of L. perenne, FLV T.p.--relative flavones content of T. pratense, Chl L.p.--relative chlorophyll content of L. perenne, Chl T.p.--relative chlorophyll content of T. pratense, $\mathrm{CP}$-crude protein, $\mathrm{CF}$ - crude fiber, $\mathrm{DOM}$ - digestibility organic matter, $\mathrm{P}$ - phosphorus, $\mathrm{K}$ - potassium, Mg—magnesium, Ca—calcium, Na—sodium; (b) for the combinations tested (2 years of studies: 2016, 2017 and Si treatment: C—control, H-Herbagreen, O-Optysil).

\section{Discussion}

A very important property of plants of grassland is their ability to give stable and high dry matter yields under different environmental condition. Due to the complexity of grassland systems, the analysis of the impact of climatic conditions and management on production stability is often hampered. Species vary in their response to changes in amount of precipitation reflecting differences in growth strategies and also genetic and phenotypic plasticity in relevant plant traits [29]. Our studies have shown differentiation of sown species share depending on the term of regrowth and year of utilization. The changes were mainly connected with weather conditions during the growing season and durability of plants. In the first and second year of research (2015 and 2016-the third and fourth year of utilization, respectively), sward was dominated by L. perenne and T. pratense. In the following year (2017-fifth year of use), especially in the second and third regrowth, T. repens was characterized by a larger share in sward. This species proved to be drought resistant and was distinguished by greater durability than other tested species. The strategy of T. repens survival in drought conditions is to reduce leaf area and transpiration and as a result these leaves wilt and die. Osmotic adjustment in T. repens stolons conserves them until water is available, and the plant can regrow from the stolon [30]. Moreover, legumes may resist drought events because they are able to utilize atmospheric dinitrogen $\left(\mathrm{N}_{2}\right)$ for their $\mathrm{N}$ requirements. This could be a valuable trait where plant-available soil $\mathrm{N}$ is increasingly constrained under drought [6]. In our experiment, the share of L. perenne decreased in the last year, which show rather low persistence of this species. Furthermore, the appearance of other species (weeds) in sward was associated with the occurrence of drought periods and the decreasing durability of sown species. Currently varieties of L. perenne show lower persistence and survival to dry and hot summer conditions than varieties of other perennial grasses (e.g., Festuca arundinacea Schreb., Dactylis glomerata L.) [31,32]. Therefore, combining grass and legumes species in simple mixtures can compensate yield reductions caused by severe drought and it offers a practical management tool to 
adapt forage production to climate change. This study demonstrated that the foliar application of silicon-containing fertilizers did not cause clear changes of botanic composition of grass-clover sward. While in the study of Radkowski et al. [33], the share of Fabaceae plants increased, and dicotyledonous plants decreased proportionally to the dose of silicon fertilization.

The magnitude of annual DM yields of grass-clover sward was in the range reported in previous studies relating to organic grassland farming [34]. According to literature it is well known that grassland productivity and rainfall are often positively correlated [35,36]. In our study, we found that rainfall deficiency in 2015 was unfavorable for plants growth and sward productivity was low. In the following year (2016), despite of higher rainfall, periodic droughts, especially during 2nd regrowth, were also observed. Aboveground biomass accumulated during the growing season in this period was low as well. Whereas the amount and distribution of rainfall in 2017 was more favorable for plants compared to the previous years. The yield dependence on weather conditions was also confirmed by plant productivity indicator LAI, which was positively correlated with aboveground biomass. Correlation coefficients calculated in subsequent years of the study $(2015,2016,2017)$ were significant and amounted to $0.97,0.52$ and 0.75 , respectively.

Productivity of grass-clover sward in organic management increased under foliar Si application as well. Simultaneously, a stronger effect was demonstrated for multicomponent Herbagreen than for growth stimulator Optysil, containing Si mainly. The results of many studies confirm the beneficial effect of Si on the mass of plants [12,37]. Favorable impact of plants Si fertilization may be a result of more effective osmoregulation, reduced water losses by transpiration, improved water balance, maintenance of a proper supply of necessary nutrients, reduced intake of toxic ions and also improved performance of antioxidant mechanisms [16]. However, our observation are clearly different from those of Radkowski et al. [33] who showed no effect of the growth stimulator Optysil on the crop yield of multispecies sward with dominance of grasses. The authors have explained this with the different ability of meadow plants to accumulate silicon. In our study, Si fertilization used was the only source of nutrients supplied to plants under organic cultivation. In the absence of additional sources of nutrients, it seems that the plants not only maximum used the nutrients supplied with Si fertilizers for the production of aboveground biomass, but the use of elements from the soil was also higher. It is suggested that $\mathrm{Si}$ could act as beneficial element under conditions of nutrient imbalance and this effect attributed to its interactions with macronutrients such as nitrogen, phosphorus or potassium, which affect crop productivity [38].

The high resilience of grass plants to water deficiency during vegetation period is associated with deep-developed root system, which enables acquisition of water from the deeper soil layers [6]. Grasses have greater allocation of biomass to roots and greater rooting depth than legumes in condition of drought stress [39]. Hoekstra et al. [40] suggest that the deep rooting trait may contribute to drought resistance, but that the effect could be small and may become important only under extreme drought conditions. Species with different functional features were used in our study: a shallow-rooted L. perenne and T. repens and a deep-rooted T. pratense. Rainfall deficiency in 2015 and 2016 (classified as very dry and moderately moist, respectively) caused increase the mass of plant roots. Proliferation of deep roots in response to drought stress in the field condition could be explained by the high degree of plasticity in response to drought exhibited by L. perenne roots [39]. Whereas T. repens despite its relatively low root biomass compared to grasses, distinguish due to drought-resistant [30].

The study demonstrated a positive effect of Si on the mass of plant roots in organic cultivation. Simultaneously, Si application in the form of Optysil growth stimulator (containing Si mainly) had a stronger impact on the root mass than the multicomponent Herbagreen fertilizer, especially in the deeper layers of soil (up to $20 \mathrm{~cm}$ ). The application of Si seems to be beneficial to plants grown under conditions of water deficiency by encouraging the development of a big root system and providing protection to roots against soil drying. Si accumulation varies considerably with the plant species and most of them are unable to accumulate high levels of $\mathrm{Si}$ in the shoots. The difference in $\mathrm{Si}$ accumulation was attributed to the ability of roots to take up this element. Therefore, although Si is abundant in soil, 
most plants, especially dicotyledonous, are unable to take up a large amount of Si from soil and have benefits from it [41]. Some monocotyledonous plants, including L. perenne [42], are characterized by a much higher intake of Si than of water, resulting in its depletion in nutrient solutions, while those with a passive or rejective $\mathrm{Si}$ uptake system take up this element at a rate similar to or even much lower than water. Legumes plants do not accumulate $\mathrm{Si}$ in tissues and tend to exclude this element. These plants take up Si more slowly than water and they contain less silicon than would be expected from nonselective passive uptake of silicic acid during plant growth [16,43].

Water shortage influences disadvantageously photosynthesis process, uptake and transport of necessary nutrients and increases production of reactive oxygen species (ROS). These reactive molecules cause to disorder in plant metabolism and damage in membranes [44]. Flavones, due to their antioxidative properties, are able to protect the plant against ROS [45]. Silicon has similar characteristics. Our research clearly indicated that flavones concentration in plants was higher in a very dry and a moderately moist year than in rainy. Simultaneously, Si application caused decreasing of flavones content especially in L. perenne plants. The reaction of $T$. pratense was evident merely in the year of moderately moist (2016). The addition of Si can also improve the concentration of chlorophyll and the structure of chloroplasts, protecting them from damage during stress [16]. In our study, Si application, independent on their form, was able to maintain a higher Chl content of both studied species (L. perenne and T. pratense) than under no Si treatment. This results indicating that the application of Si could decrease the decomposition of photosynthetic pigments under stress of water deficit.

Water deficiency very often leads to impairment of mineral nutrition of plants and disruptions in ion homeostasis. Silicon is able to modify biologic properties of soil (e.g., by increasing the biomass of microbial $\mathrm{N}$ fixers) [46] and to improve uptake and accumulation of macro- and micronutrients in various plant species [47]. According to Kurdali et al. [48], water shortage negatively affects the nitrogen balance in the plant due to a reduction of ability to bind atmospheric nitrogen. They have also concluded that application of $\mathrm{Si}$ is not only involved in amelioration of growth and in maintaining of water status, but it can be also considered an important element for the symbiotic nitrogen fixation of Cicer arietinum plants, especially in the synergistic action of silicon and potassium fertilization. Some investigations indicate that application of $\mathrm{Si}$ may increase concentration of calcium in plant tissues and hence restore membrane integrity in plants under condition of water deficiency [16]. In the study of Siam et al. [38], potassium and phosphorus content and uptake by the different parts of rice plant (roots, shoots and grains) significantly increased by Si addition to the used fertilizers.

Our study showed impact of both weather conditions in the years and Si fertilization on the nutrient content of the grass-clover sward. In agreement with a previous studies our results suggest that under drought, Si-alleviated effects were associated with an increase in phosphorus, calcium and potassium concentration in grass-clover sward. The study also showed, that under conditions of less rainfall, both fertilizers reduced the content of crude fiber and increased the digestibility of organic matter. Beneficial effect of Si on crude protein content, independent of weather conditions, only with fertilization multicomponent Herbagreen was observed. The sward fertilized with Optysil was characterized by crude protein content similarly to that which was not treated with Si. In contrast Radkowski et al. [33] reported, that the silage made from the crops fertilized with the growth stimulator Optysil showed a tendency for a higher total protein content. They suggested that this could be due to a higher proportion of legume plants in the botanical composition of the meadow and an increased protein content in these plants.

In conclusion, this study was established that supplying Si under field conditions in organic cultivation leads to better of grass-clover sward productivity. This effect is especially visible when the plants are cultivated with multicomponent $\mathrm{Si}$ fertilizer enabling good development of aboveground part of plants and dry matter yield. Simultaneously, Si application in the form of growth stimulator, containing Si mainly, had a beneficial impact on the plant roots mass by encouraging the development of a big root system, especially under water deficiency. In such conditions the application of $\mathrm{Si}$ decreased flavones concentration in plants and increased chlorophyll index. In addition, this study 
indicates the potential for applying Si fertilizers to improve content of nutrients $(\mathrm{CP}, \mathrm{DOM}, \mathrm{K}, \mathrm{P})$ in the sward from temporary grassland in organic cultivation. The results of these studies can be used in practice of fertilization of organic crop for enhancing sward productivity and also to compensate yield losses under predicted drought scenarios.

Author Contributions: Conceptualization, G.M.; formal analysis, G.M.; investigation, G.M., B.B.-J., P.D., E.S., A.P. and B.W.; methodology, G.M., B.B.-J., E.S. and B.W.; supervision, G.M.; visualization, G.M.; writing-original draft, G.M.; writing-review \& editing, G.M. and B.B.-J. All authors have read and agreed to the published version of the manuscript.

Funding: This research received no external funding.

Conflicts of Interest: The authors declare no conflict of interest.

\section{References}

1. Vicca, S.; Gilgen, A.K.; Serrano, M.C.; Dreesen, F.E.; Dukes, J.S.; Estiarte, M.; Gray, S.B.; Guidolotti, G.; Hoeppner, S.; Leakey, A.D.B.; et al. Urgent need for a common metric to make precipitation manipulation experiments comparable. New Phytol. 2012, 195, 518-522. [CrossRef] [PubMed]

2. Thumm, U.; Tonn, B. Effect of precipitation on dry matter production of a meadow with varied cutting frequency. Grassl. Sci. Eur. 2010, 15, 90-92.

3. Trnka, M.; Eitzinger, J.; Gruszczynski, G.; Buchgraber, K.; Resch, R.; Schaumberger, A. A simple statistical model for predicting herbage production from permanent grassland. Grass Forage Sci. 2006, 61, $253-271$. [CrossRef]

4. Vogel, A.; Scherer-Lorenzen, M.; Weigelt, A. Grassland resistance and resilience after drought depends on management intensity and species richness. PLOS ONE 2012, 7. [CrossRef]

5. Lüscher, A.; Mueller-Harvey, I.; Soussana, J.F.; Rees, R.M.; Peyraud, J.L. Potential of legume-based grassland-Livestock systems in Europe: A review. Grass Forage Sci. 2014, 69, 206-228. [CrossRef]

6. Hofer, D.; Suter, M.; Haughey, E.; Finn, J.A.; Hoekstra, N.J.; Buchmann, N.; Lüscher, A. Yield of temperate forage grassland species is either largely resistant or resilient to experimental summer drought. J. Appl. Ecol. 2016, 53, 1023-1034. [CrossRef]

7. Wilkinson, J.M.; Lee, M.R.F.; Rivero, M.J.; Chamberlain, A.T. Some challenges and opportunities for grazing dairy cows on temperate pastures. Grass Forage Sci. 2020, 75, 1-17. [CrossRef]

8. Gawel, E. The protein yield in organic cultivated papilionaceous-grass mixtures. J. Res. Appl. Agric. Eng. 2010, 55, 80-85.

9. Jankowska-Huflejt, H.; Domański, P.J. Present and possible directions of grassland use in Poland. Woda Środowisko Obszary Wiejskie 2008, 8, 31-49.

10. Gaweł, E. Nutritive value of legume-grass mixtures cultivated in organic farms. J. Res. Appl. Agric. Eng. 2012, 57, 91-97.

11. Artyszak, A. Effect of silicon fertilization on crop yield quantity and quality-A literature review in Europe. Plants 2018, 7, 54. [CrossRef] [PubMed]

12. Artyszak, A.; Gozdowski, D.; Kucińska, K. The effect of foliar fertilization with marine calcite in sugar beet. Plant. Soil Environ. 2014, 60, 413-417. [CrossRef]

13. Jarosz, Z. The effect of silicon application and type of substrate on yield and chemical composition of leaves of cucumber. J. Elementol. 2013, 18, 403-414. [CrossRef]

14. Górecki, R.S.; Danielski-Busch, W. Effect of silicate fertilizers on yielding of greenhouse cucumber (Cucumis sativus L.) in container cultivation. J. Elementol. 2009, 14, 71-78.

15. Hogendorp, B.K. Effect on Silicon-Based Fertilizer Application on the Development and Reproduction of Insect Pests Associated with Greenhouse-Grown Crops. Ph.D. Thesis, University of Illinois, Urbana, IL, USA, 2008.

16. Sacała, E. Role of silicon in plant resistance to water stress. J. Elem. 2009, 14, 619-630. [CrossRef]

17. Gunes, A.; Inal, A.; Bagei, E.G.; Coban, S.; Pilbeam, D.J. Silicon mediates changes to some physiological and enzymatic parameters symptomatic for oxidative stress in spinach (Spinatia oleraces L.) grown under B toxicity. Sci. Hort. 2007, 113, 113-119. [CrossRef] 
18. Mateos-Naranjo, E.; Andrades-Moreno, L.; Davy, A.J. Silicon alleviates deleterious effects of high salinity in the halophytic grass Spartina densiflora. Plant. Physiol. Biochem. 2013, 63, 115-121. [CrossRef]

19. Rubinowska, K.; Pogroszewska, E.; Laskowska, H.; Szot, P.; Zdybel, A.; Stasiak, A.; Kozak, D. The subsequent effect of silicon on physiological and biochemical parameters of Polygonatum multiflorum (L.) All. 'Variegatum' cut shoots. Acta Sci. Pol-Hortoru 2014, 13, 167-178.

20. Kaya, C.; Tuna, L.; Higgs, D. Effect of silicon on plant growth and mineral nutrition of maize grown under water-stress conditions. J. Plant. Nutr. 2006, 29, 1469-1480. [CrossRef]

21. Ma, J.F.; Takahashi, E. Soil, Fertilizer, and Plant Silicon Research in Japan; Elsevier: Amsterdam, The Netherlands, 2002; pp. 1-292.

22. Ahmad, S.T.; Haddad, R. Study of silicon effects on antioxidant enzyme activities and osmotic adjustment of wheat under drought stress. Czech. J. Genet. Plant. Breed. 2011, 47, 17-27. [CrossRef]

23. Matichenkov, V.V.; Bocharnikova, E.A.; Ammosova, J.M. The influence of silicon fertilizers on the plants and soils. Agrochemistry 2001, 12, 30-37.

24. Hattori, T.; Inanaga, S.; Tanimoto, E.; Lux, A.; Luxová, M.; Sugimoto, Y. Silicon-induced changes in viscoelastic properties of sorghum root cell walls. Plant. Cell Physiol. 2003, 44, 743-749. [CrossRef] [PubMed]

25. Sahebi, M.; Hanafi, M.M.; Akmar, A.S.; Rafii, M.Y.; Azizi, P.; Tengoua, F.F.; Azwa, J.N.M.; Shabanimofrad, M. Importance of Silicon and mechanisms of Biosilica Formation in Plants. BioMed Res. Int. 2015, 2015, 1-16. [CrossRef] [PubMed]

26. FAO. World Reference Base for Soil Resources (WRBSR) 2014. International Soil Classification System for Naming Soils and Creating Legends for Soil Maps; World Soil Resources Report; FAO: Rome, Italy, 2015.

27. Goss, M. Root distribution, growth and turnover. In Sward Measurement Handbook, 2nd ed.; Davies, A., Baker, R.D., Grant, S.A., Laidlaw, A.S., Eds.; British Grassland Society: Reading, UK, 1993; pp. 157-182.

28. Vinczeffy, J. The effect of some ecological factors on grass yield. In Proceedings of the 10th General Meeting of European Grassland Federation, Ås, Norway, 26-30 June 1984; European Grassland Federation: Ås, Norway, 1984; pp. 76-79.

29. Bristiel, P.; Roumet, C.; Violle, C.; Volaire, F. Coping with drought: root trait variability within the perennial grass Dactylis glomerata captures a trade-off between dehydration avoidance and dehydration tolerance. Plant. Soil 2019, 434, 327-342. [CrossRef]

30. Karsten, H.D.; MacAdam, J.W. Effect of drought on growth, carbohydrates, and soil water use by perennial ryegrass, tall fescue, and white clover. Crop. Sci. 2001, 41, 156-166. [CrossRef]

31. Sanna, C.; Franca, A.; Porqueddu, C.; Piluzza, G.; Re, G.A.; Sulas, L.; Bullitta, S. Characterization of native perennial ryegrasses for persistence in mediterranean rainfed conditions. Span. J. Agric. Res. 2014, 12, 1110-1123. [CrossRef]

32. Lelièvre, F.; Volaire, F. Current and potential development of perennial grasses in rainfed Mediterranean farming systems. Crop. Sci. 2009, 49, 2371-2378. [CrossRef]

33. Radkowski, A.; Sosin-Bzducha, E.; Radkowska, I. Effects of silicon foliar fertilization of meadow plants on nutritional value of silage fed to dairy cows. J. Elem. 2017, 22, 1311-1322.

34. Klaus, V.H.; Kleinebecker, T.; Prati, D.; Gossner, M.M.; Alt, F.; Boch, S.; Gockel, S.; Hemp, A.; Lange, M.; Müller, J.; et al. Does organic grassland farming benefit plant and arthropod diversity at the expense of yield and soil fertility? Agric. Ecosyst. Environ. 2013, 177, 1-9. [CrossRef]

35. Guo, Q.; Hu, Z.M.; Li, S.G.; Li, X.R.; Sun, X.M.; Yu, G.R. Spatial variations in aboveground net primary productivity along a climate gradient in Eurasian temperate grassland: effects of mean annual precipitation and its seasonal distribution. Glob. Chang. Biol. 2012, 18, 3624-33631. [CrossRef]

36. Nippert, J.B.; Knapp, A.K.; Briggs, J.M. Intra-annual rainfall variability and grassland productivity: Can the past predict the future? Plant. Ecol. 2006, 184, 65-74. [CrossRef]

37. Radkowski, A.; Radkowska, I. Effects of silicate fertilizer on seed yield In timothy-grass (Phleum pratense L.). Ecol. Chem. Eng. S 2018, 25, 169-180. [CrossRef]

38. Siam, H.S.; Abd El-Moez, M.R.; Holah, S.S.; AbouZeid, S.T. Effect of silicon addition to different fertilizer on yield of rice (Oryza sativa L.) plants. I-Macro nutrients by different rice parts. Middle East. J. Appl. Sci. 2018, 8, 177-190.

39. Skinner, R.H.; Comas, L.H. Root distribution of temperate forage species subjected to water and nitrogen stress. Crop Sci. 2010, 50, 2178-2185. [CrossRef] 
40. Hoekstra, N.J.; Suter, M.; Finn, J.A.; Husse, S.; Lüscher, A. Do belowground vertical niche differences between deep-And shallow rooted species enhance resource uptake and drought resistance in grassland mixtures? Plant. Soil 2015, 394, 21-34. [CrossRef]

41. Ma, J.F. Role of silicon in enhancing the resistance of plants to biotic and abiotic stresses. Soil Sci. Plant. Nutr. 2004, 50, 11-18. [CrossRef]

42. Jarvis, S.C. The uptake and transport of silicon by perennial ryegrass and wheat. Plant. Soil 1987, 97, 429-438. [CrossRef]

43. Liang, Y.; Si, J.; Römheld, V. Silicon uptake and transport is an active process in Cucumis sativus. New Phytol. 2005, 167, 797-804. [CrossRef]

44. Reddy, A.R.; Chiatanya, K.V.; Vivekanandan, M. Drought-induced responses of photosynthesis and antioxidant metabolism in higher plants. J. Plant. Physiol. 2004, 161, 1189-1202. [CrossRef]

45. Mierziak, J.; Kostyn, K.; Kulma, A. Flavonoids as important molecules of plant interactions with the environment. Molecules 2014, 19, 16240-16265. [CrossRef]

46. Rangaraj, S.; Gopalu, K.; Rathinam, Y.; Periasamy, P.; Venkatachalam, R.; Narayanasamy, K. Effect of silica nanoparticles on microbial biomass and silica availability in maize rhizosphere. Biotechnol. Appl. Biochem. 2014, 61, 668-675. [CrossRef] [PubMed]

47. Greger, M.; Landberg, T.; Vaculík, M. Silicon influences soil availability and accumulation of mineral nutrients in various plant species. Plants 2018, 7, 41. [CrossRef] [PubMed]

48. Kurdali, F.; Al-Chammaa, M.; Mouasess, A. Growth and nitrogen fixation in silicon and/or potassium fed chickpeas grown under drought and well-watered conditions. J. Stress Physiol. Biochem. 2013, 9, 386-406.

(C) 2020 by the authors. Licensee MDPI, Basel, Switzerland. This article is an open access article distributed under the terms and conditions of the Creative Commons Attribution (CC BY) license (http://creativecommons.org/licenses/by/4.0/). 